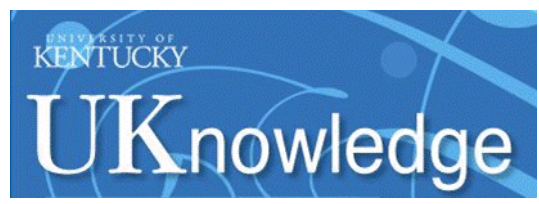

University of Kentucky

UKnowledge

\title{
Social Responsibility, Librarianship, and the ALA: The 2015 Banned Books Week Poster Controversy
}

\author{
Emily J. M. Knox \\ University of Illinois \\ Shannon M. Oltmann \\ University of Kentucky, shannon.oltmann@uky.edu
}

Follow this and additional works at: https://uknowledge.uky.edu/slis_facpub

Part of the Library and Information Science Commons

Right click to open a feedback form in a new tab to let us know how this document benefits you.

\section{Repository Citation}

Knox, Emily J. M. and Oltmann, Shannon M., "Social Responsibility, Librarianship, and the ALA: The 2015 Banned Books Week Poster Controversy" (2018). Information Science Faculty Publications. 41.

https://uknowledge.uky.edu/slis_facpub/41

This Article is brought to you for free and open access by the Information Science at UKnowledge. It has been accepted for inclusion in Information Science Faculty Publications by an authorized administrator of UKnowledge. For more information, please contact UKnowledge@lsv.uky.edu. 
Social Responsibility, Librarianship, and the ALA: The 2015 Banned Books Week Poster Controversy

Digital Object Identifier (DOI)

https://doi.org/10.1086/694870

Notes/Citation Information

Published in The Library Quarterly, v. 88, no. 1, p. 5-22.

(c) 2018 by The University of Chicago. All rights reserved.

The copyright holder has granted the permission for posting the article here.

This article is available at UKnowledge: https://uknowledge.uky.edu/slis_facpub/41 


\title{
Social Responsibility, Librarianship, and the ALA: The 2015 Banned Books Week Poster Controversy
}

\section{Emily J. M. Knox and Shannon M. Oltmann}

\begin{abstract}
This article explores the recent controversy over the American Library Association's poster for Banned Books Week. In particular, this article connects the 2015 controversy to broader historical issues and tensions within American librarianship concerning social responsibilities. The researchers used a qualitative approach, conducting telephone interviews with 26 individuals. The interviews were recorded, transcribed, and analyzed deductively. The interviews revealed deep continuing tensions regarding American librarianship's relationship to responsibilities. First, there is some dissatisfaction with the American Library Association and its Office for Intellectual Freedom. Second, there are competing conceptualizations of censorship and how to apply these differing meanings while remaining socially responsible. Third, there is uncertainty about how to appropriately act as an ally, within librarianship, to marginalized peoples.
\end{abstract}

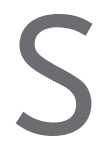

pearheaded by Judith Krug in 1982, Banned Books Week (BBW) is a national annual campaign for awareness about censorship in the United States that is "celebrated" in libraries and bookstores across the country. BBW is cosponsored by the American Library Association (ALA), the American Booksellers Association, the American Booksellers Foundation for Free Expression, the American Society of Journalists and Authors, the Association of American Publishers, and the National Association of College Stores. It is also endorsed by the Center for the Book at the Library of Congress. Public, school, and academic libraries host read-ins, display banned and challenged books, and create displays.

BBW is supported by the ALA's Office for Intellectual Freedom (OIF), and proceeds from advertisement sales support the office. The ALA chooses a new theme each year and sells several products such as bookmarks, T-shirts, and mugs, although the main advertisement is large posters. The advertising themes have ranged from a flag to a robot pulling out his plug and saying, "Think for yourself and let others do the same," to pictures of books with the words "Forbidden" and "Banned" printed across the texts. Over the years, some campaigns have sold better than others, but none of the advertising was particularly controversial until 2015.

Library Quarterly: Information, Community, Policy, vol. 88, no. 1, pp. 5-22. (C) 2018 by The University of Chicago. All rights reserved. $0024-2519 / 2018 / 8801-0002 \$ 10.00$ 
The controversy over the 2015 BBW theme and advertising primarily centered on visual and symbolic interpretations of the large poster. In this article, we use in-depth, semistructured interviews to trace the development and escalation of the controversy and to provide insight into the perspectives of both those who supported and those who opposed the poster. Three themes related to social responsibilities emerged from our research. First, there are ongoing concerns within American librarianship about the ALA and OIF and the OIF's stance on social responsibility. Second, we demonstrate that librarians themselves use multiple definitions of censorship and its relationship to social responsibility, and finally, there are prevalent problems in how to support marginalized members of society, which we term the problem of "allyship." This article explores how and why the 2015 BBW poster became the newest flash point in contemporary librarianship.

\section{Background}

The ALA and librarianship have had many controversies over the years. For example, the "fiction question" and the place of the novel in libraries roiled librarianship in the United States in the 1880 s and beyond (Geller 1984). In the 1950s during the Communist Red Scare there was a controversy about whether to label propaganda within US libraries. Although the ALA officially opposed labeling, this controversy exposed a tension between liberal and progressive values in librarianship (Robbins 1993). The controversy that most clearly demonstrated this tension took place in the 1960 and centered on the rise of a social responsibility movement in librarianship and eventually led to the establishment of the Social Responsibilities Round Table (SRRT). "Social responsibilities" are the obligations that a particular organization (or, more widely, the profession) has to society. Toni Samek's (2001) research traces this history and notes that the ALA never endorsed one definition of intellectual freedom, simply arguing that it is the opposite of censorship. There was also concern that the Library Bill of Rights, which had been adopted in 1938, was simply a shield for prejudice by allowing all opinions of an issue to be admitted into library collections, even if those opinions could be harmful to others.

Eventually, the ALA explored these issues through the creation of two ad hoc committees, ACONDA (Activities Committee on New Directions) and ANACONDA (Ad Hoc Activities Committee on New Directions) in the late 196os. However, the work of these committees did not lead to a resolution on the place of social responsibility within American librarianship. As Douglas Raber (2007) suggests, professionals had no clear idea of how to define social responsibility. Samek (2001), however, argues that committee work led to two accepted understandings of the term within the profession. First, librarianship should keep the traditional value of reflecting all sides, but it should not promote all sides. Second, librarianship should contribute to social welfare (Samek 2001). The ALA also established the SRRT, but Samek argues that the roundtable's mission was "smothered" by the development of other roundtables with mis- 
sions that overlapped with the SRRT's. Of these committee-based attempts to grasp social responsibility and the role of librarianship, only the SRRT is still extant and active.

In 1977 another controversy erupted at the ALA annual conference in Detroit, Michigan, with the ALA-produced film The Speaker. As noted by Phil Morehart and George M. Eberhart (2014), the ALA commissioned a film that explored the ramifications of having a controversial speaker on a high school campus. According to the ALA, the movie is "a dramatization about a high school current events committee which invites a university professor to speak on a theory of genetic inferiority of Afro-Americans. Controversy develops and spills over into the community and parents and community leaders advise the student committee to reconsider. . . . [It is] intended to evoke discussion of constitutional protection of speech on controversial and unpopular topics" (ALA 2014). Some members of ALA argued that the film was racist, and the ALA executive board initially voted to delay the screening, but this vote was rescinded and the film was shown as planned at the 1977 annual conference. It is clear from news reports written at the time that many ALA members felt that issues of social justice and intellectual freedom that the film brought to the surface were not resolved. As John Berry (1977) wrote in an article titled, "The Debate Nobody Won," for Library Journal: "It is . . a apparent that neither side of the debate on The Speaker has moved, even slightly, to acceptance of the argument presented by the other" (1580). This same intransigence could be found when the ALA showed the film and held a panel discussion about it at the 2014 annual conference (Kagan 2014).

In the years since the establishment of the SRRT and The Speaker controversy, the relationship between librarianship and social responsibilities has become ever more prominent in the field. As Paul Jaeger and colleagues (2015) note, the values of diversity and inclusion have only recently been part of LIS education and practice. As shown in our research, perceived tension continues between the practice of social responsibility and support for other traditional values in librarianship such as intellectual freedom. The 2015 BBW poster controversy echoes previous controversies concerning social responsibilities librarianship in many respects.

\section{Overview of 2015 Controversy}

In early April 2015, the ALA released the BBW campaign featuring a poster of a woman on a blue background holding a book with a bar across her face (see fig. 1). The woman has brown skin, long hair, and bare arms. The design was intended to look like a Do Not Enter sign and included the word "Readstricted," a portmanteau of "read" and "restricted." Many people saw the poster as a thumbnail image, in which many details were difficult to see.

Soon after its release, the design was the subject of criticism across social media and various library-related electronic mailing lists (see table 1). Some within the library community argued that the poster looked like a woman in a niqab (often erroneously called a "burqa"), a female 


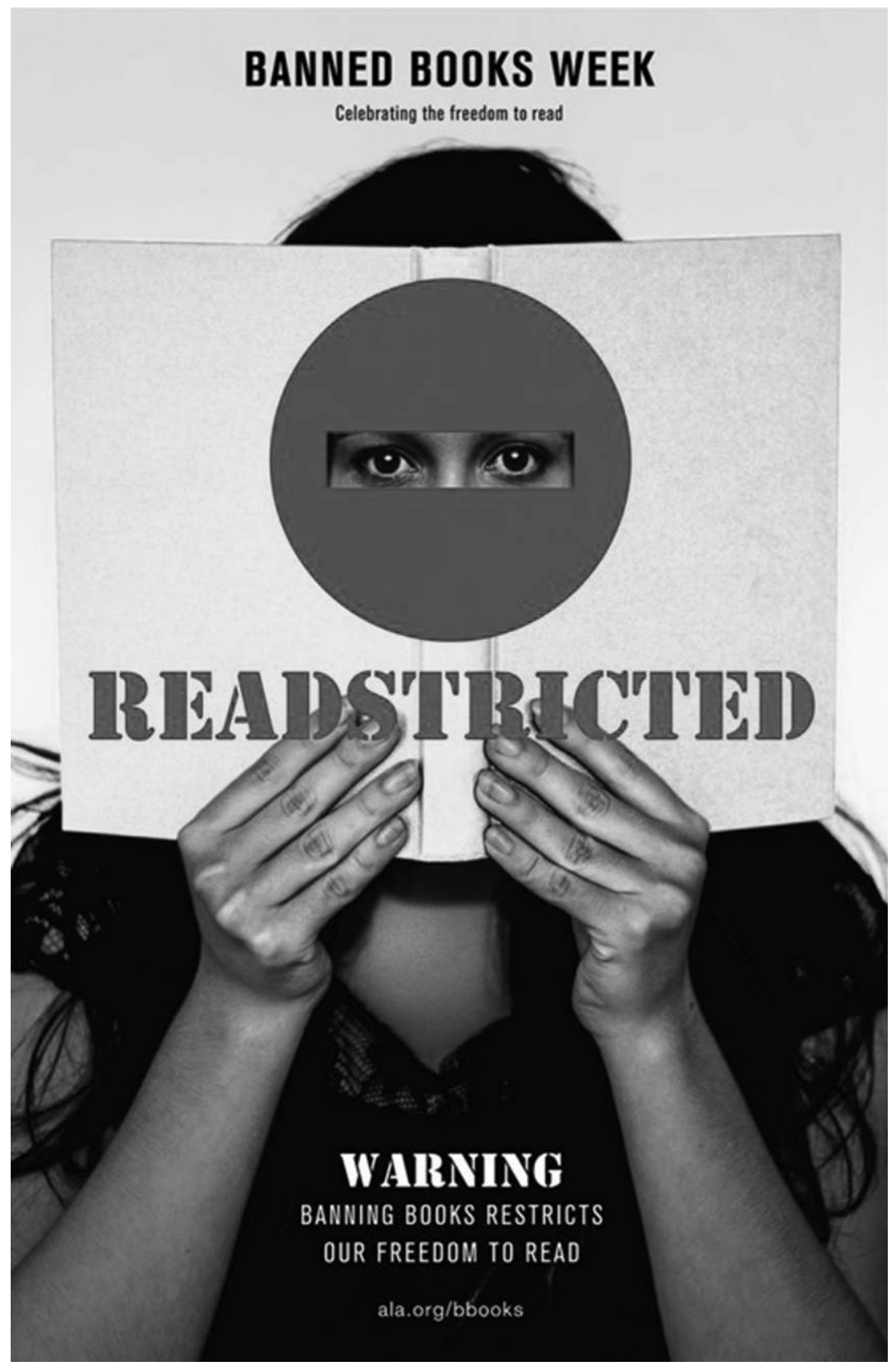

Figure 1. 2015 Banned Books Week poster. Used with permission of the American Library Association. Color version available online. 
Table 1. Timeline of Events Related to BBW Poster Controversy

\begin{tabular}{ll}
\hline Date in 2015 & \multicolumn{1}{c}{ Event } \\
\hline April 8 & $\begin{array}{c}\text { Poster released to the general public and made available in } \\
\text { ALA store }\end{array}$ \\
April 10 & Facebook threads begin (ALA ThinkTank) \\
April 10 & E-mail threads about poster begin on electronic mailing lists \\
April 12 & Petition to remove poster started on change.org \\
April 15 & OIF posts blog and electronic mailing list updates explaining resolution
\end{tabular}

Muslim sartorial style that covers everything but the eyes. Others, particularly those working for OIF or associated with it, did not see anything controversial about the image.

Over the past few decades, the ALA has striven to be a more diverse and inclusive organization, but for many commenters, the poster seemed to embody the opposite of these ideals. In response to the controversy, the OIF released two official statements addressing the concerns about the poster. The office stated that the poster was intended to show "diversity" and, furthermore, was designed by a Muslim woman. This response did little to assuage the concerns of many commenters, and the OIF was accused of being defensive and of engaging in tokenism. OIF issued alternative posters, which were identical except the woman was removed. In addition, the office developed an unofficial policy that no more human images will be used in the annual BBW advertisements.

The controversy over the 2015 BBW poster embodies many long-standing disputes in librarianship, especially the tension among the values of intellectual freedom, social justice, and social responsibility. As Samek (2001) notes in Intellectual Freedom and Social Responsibility in American Librarianship, 1967-1974, there has long been a concern within librarianship that support for intellectual freedom is simply a shield for upholding prejudices. The tension between the drive to work for a more just society and to uphold the freedom to access any knowledge that one chooses is one that has been a point of controversy in librarianship since the field's professionalization in the late nineteenth century.

\section{Method}

To more fully explore the BBW controversy, we conducted 26 semistructured interviews with members of the library community and the staff of the OIF. Interviews are an effective method for probing "beneath the surface, soliciting detail and providing a holistic understanding of the interviewee's point of view" (Patton 1987, 108). Darren Lilleker (2003) explains that "interviews can provide immense amounts of information that could not be gleaned from official published documents or contemporary media accounts" (208). Because the interviewees were geographically dispersed and because this was a potentially sensitive topic, telephone interviews were used (Oltmann 2016). 
Because of the timely nature of the controversy and of much of the discussion location on social media, members of the library community were solicited in posts to Facebook, Twitter, and relevant library electronic mailing lists. We supplemented this convenience sample with a snowball sample to contact those who might not have seen the requests for interviewees through electronic channels. All interviewees had seen the poster prior to being interviewed and responded to the request for interviews, presumably because they felt that they had something to say on this topic.

All five members of the OIF staff were interviewed, along with 21 individuals from the broader librarian community; participants were students, librarians from all types of libraries, a consultant, a patron, and a library science professor (see table 2). Public librarians were the most heavily represented, with eight responders. These descriptions are purposely vague to protect interviewees' confidentiality. Those who worked in the OIF at the time of the controversy will be identified as "staff," and all other interviewees who responded to the poster will

Table 2. Summary of Interviews

\begin{tabular}{lc}
\hline Individual & Length of Interview (Minutes) \\
\hline Academic librarian 1 & $20: 21$ \\
Academic librarian 2 & $37: 59$ \\
Librarian (unspecified) & $22: 05$ \\
Library blogger and consultant & $15: 57$ \\
Library science professor & $16: 49$ \\
Library science student 1 (LIS postdoc) & $16: 30$ \\
Library science student 2 & $8: 49$ \\
Library science student 3 & $10: 06$ \\
OIF staff 1 & $16: 27$ \\
OIF staff 2 & $15: 17$ \\
OIF staff 3 & $20: 04$ \\
OIF staff 4 & $12: 43$ \\
OIF staff 5 & $15: 35$ \\
Patron & $18: 06$ \\
Public librarian 1 & $25: 49$ \\
Public librarian 2 & $25: 46$ \\
Public librarian 3 & $15: 47$ \\
Public librarian 4 & $8: 50$ \\
Public librarian 5 & $25: 33$ \\
Public librarian 6 & $8: 16$ \\
Public librarian 7 & $10: 50$ \\
Public librarian 8 & $8: 43$ \\
School librarian 1 & $28: 21$ \\
School librarian 2 & $20: 39$ \\
Special librarian 1 & $25: 44$ \\
Special librarian 2 & $8: 12$ \\
& \\
\hline &
\end{tabular}


be referred to by job title. There were 12 non-OIF staff interviewees who were against the poster, 6 who were supportive, and 3 most easily characterized as ambivalent. Interviews ranged from 8:12 to 37:59 minutes long, with an average length of 17:40. They took place over the phone in fall 2015. All interviews were recorded, transcribed, and coded for common themes.

\section{Themes}

We found three common themes concerning social responsibilities in the interviewees' discourse. First, several responders expressed concern and frustration with OIF or ALA generally. Second, interviewees gave varying conceptions of censorship and its relationship to social responsibility, which affected how they saw and responded to the BBW poster. Third, interviewees wrestled with ideas of how to support cultural and racial minorities (or allyship) as part of upholding the values of social responsibilities.

\section{View of ALA and the OIF}

The first theme that came up in interviews is that the interviewees' interpretations of both the poster and the OIF's response to it were colored by their views of the association as a whole, and of the OIF in particular. As noted in the "Background," the ALA has long been a subject of criticism in the profession, and in some respects, the BBW poster controversy was simply a continuation of a dialogue about who and what the ALA represents.

This discussion often centered on what it means to be a membership organization, and interviewees sometimes accused the association of not being attuned to the needs of its members: "As an ALA member, I have a problem with that too, you know. I mean my voice is, my voice is as valid as anybody else's. I mean, I pay my membership dues as well so you know I think that I deserve at least some consideration in this rather than it turning into a back-andforth, you know, he said/she said, you done, you know, he done/she done" (Public librarian 5). Another noted that the controversy over the poster spread to more members than just the ones who usually criticized the actions of the ALA, which meant that "it's very hard for them to just consider it, you know, some sort of political tempest in a teapot and then just go about their business" (Special librarian 1). One public librarian felt that this controversy was just one more in a long list of problems with the ALA. Some interviewees were simply disappointed in the OIF and said this would have an effect on their support for future work of the office: "I was very surprised and I was really, really disappointed in the Office for Intellectual Freedom for the way that they handled it. I mean extremely, extremely disappointed to the point where I'm now no longer interested in supporting the Freedom to Read Foundation. . . . I am very, very dubious whenever I see something from the Office for Intellectual Freedom because I really felt that their response to it was incredibly unprofessional and really just bad, just a really, really bad response" (Public librarian 5). One librarian argued that the ALA should use this controversy as an opportunity to open up the conversation on challenges: 
But it's really difficult for me to support Banned Books Week with all my heart because I feel like we could be having a more genuine conversation about challenges, about the fact that challenges are often coming from the religious right, about the fact that challenges are often coming from a very small group of people with a very large megaphone, and we can't have that conversation because we spend so much time reading Catcher in the Rye to each other, which I don't actually think is what the true threat is anymore, and it would be neat to see ALA having that conversation. (Librarian)

These responders were frustrated with the bureaucracy of the ALA and the OIF and what they saw as the lack of responsiveness and sensitivity to issues of diversity and inclusion. Some interviewees felt that this large organization, with a membership of more than 60,000 (ALA 2016a), did not hear or respect their voices (though we must note that this opinion was shared by few interviewees). These were passionate librarians who wanted a responsive organization but did not see it in the ALA.

In contrast, the relationship of the OIF and, more broadly, the ALA to members was not an issue raised by OIF staff members in their interviews. They were unaware of the disconnection between their work and how it was perceived by several responders. It is likely the staff members see their daily activities of advocating for librarians who are facing challenges as sufficiently supportive and representative of the whole librarian community. Some of the OIF staff understood that the responders were acting from good intentions: "I think the ALA is very fortunate and special in that they attract and assemble a group of very thoughtful and caring people who are passionate about their principles and beliefs and that's what makes ALA unique. And so because of that, I think that the people who raised the concerns were well-meaning, wellintentioned. But I also think that, respectfully, I think they were shortsighted” (OIF staff 2). This staff person was able to appreciate the ALA members even though she did not agree with their interpretation of or actions responding to this poster.

\section{Definitions of Censorship}

Another major theme of the interviews concerned definitions of censorship and supporting intellectual freedom while also fulfilling the social responsibilities of the profession. Emily Knox (2014) has argued that there are broad and narrow definitions of censorship. Those who use narrow definitions often argue that only the government has the power to censor, whereas those who use broad definitions state that any entity has the power to censor. One interviewee expressed this sentiment by using the terms "small c" and "capital C" censorship:

I want to make a distinction between censorship as a government activity, where the government in some form steps in and suppresses ideas in some way, and a prominent 
association making a decision that this doesn't reflect our group. On the other hand, we stand against censorship even in the small sense, in that 'lower c' sense and that we would be setting a pretty bad example if we, based upon the level of concern expressed - remember, all we got was a few dozen, I won't say a few dozen; it might have been even 100 responses on a web survey raising questions and no formal process to really sample the membership, etc. (Academic librarian 1)

It should be noted that the official statements of the ALA are based on a broad definition of censorship (see, e.g., the Library Bill of Rights; ALA 2016b). Those who did not want the poster pulled used similarly broad conceptions of censorship. Not surprisingly, as will be shown, librarians who were offended and wanted the poster pulled had narrow definitions of censorship. For example, one interviewee argued that pulling the poster had nothing to do with free speech:

I definitely was in the camp of folks who thought we should change the poster. I understand that people took that as a free speech issue like we were censoring ourselves by not using this poster. I don't think, to me that's not what free speech means. I mean absolutely we had the right to use that poster if we wanted to, but if it's something that we've already heard back from people that they find it offensive, it's, you know it's not fine. Like you know a simple pragmatic sense, it's not wise to go ahead with that image. (Public librarian 6)

Here we can see that, for this responder, free speech and the use of the poster were not related. Because someone could still use the poster, changing the poster would not infringe on anyone's right to free speech.

Another interviewee stated that the ALA and OIF were simply using the wrong definition of censorship: “That's not, I mean I was deeply offended that they used this censorship, you know, 'shield' as a cover because, I mean, I feel like it's just wrapping . . . themselves in the Library Bill of Rights; they wrap themselves behind this, you know, word of 'censorship,' and it's a complete misnomer; it's ridiculous" (Public librarian 5). A school librarian argued that the poster should be removed because the message of BBW had been lost in the controversy.

Several interviewees stated that the commercial nature of the poster made pulling the poster different from censorship. One compared the poster to books: "Censoring Heather Has Two Mommies or, you know, great works of literature that have won the Nobel Prize and Pulitzers is censorship. Complaining about a PR campaign that's designed to raise consciousness about censorship that you know is inadvertently not working, that's not censorship" (Academic librarian 2). Here we see that censorship is narrowly defined as being outside of the public relations realm. This is also echoed in the statements of a professor of library 
science: "I don't see any intellectual freedom issues in just pulling the advertising" (LIS professor). Removing advertising, for these responders, is inherently different from censoring in a library. Another focused on how the poster is simply a "product" (Public librarian 5). Finally, some responders said that if it is not censorship when companies pull their offensive products, then the same holds for the ALA: "No, well, I mean, BIC pulled their pink pens for ladies; it's sort of the same thing. When you're advertising a product like Banned Books Week, I didn't think of it as necessarily . . . it wasn't like art-it was advertising. When advertising doesn't work, you don't use it" (Public librarian 7). Commercialism was one of the primary justifications given for pulling the poster. As shown, responders argued that because the poster was part of an advertising campaign, the ALA should be able to easily change the poster without consideration for principles of free speech.

In contrast, several librarians and - not surprisingly — the OIF staff held broad views of censorship and argued vociferously that pulling the poster was a form of censorship and that such an act would lead to a loss of credibility for the OIF and the wider association. As one public librarian noted:

And then, so, it was very much like, that's what I see out of it is like the, a little bit of a cognitive dissonance where it's, on one hand, yeah, we're here for, we have offensive materials; on the other hand, people are calling for this, you know, this content to be removed because it's offensive, and the fact that the Office for Intellectual Freedom, there's no way they can remove it because they're, it's their credibility on the line. I think they handled it very well, in terms of making it available without the figure in it and making an alternative poster available because that's, you know, that certainly makes-it's a good out. (Public librarian 3)

Some responders were concerned about whether pulling the poster was an "extreme" response: "I thought that [pulling the poster] was, excuse me, a little extreme, but again, you know, I was sort of deferring to people that may have a better take on what the issues were to particular communities. And so just because it didn't bother me didn't mean that it shouldn't bother other people. ... To me, it sort of came down to one of those things where it's unclear how offensive it was, and if it was potentially offensive to a very small portion of people, does that warrant being yanked?" (Special librarian 2). A school librarian argued that pulling the poster would give the impression that the Muslim community does not support free speech: "I feel like to try to censor a poster about censorship, you know, is wrong. And just to speak further on it, if the person was hypothetically Muslim, my question would be this: what would even be wrong with that? If you have a Muslim person promoting free speech, is that not something that we would want to do with every ethnic group, with every religion, you know? I mean the freedoms of the First Amendment and intellectual freedom, to me, transcend things like that, you know" (School librarian 1). It should be noted that this inter- 
pretation is exactly the opposite of those of other responders who stated that the image on the poster indicated that Muslims do not support free speech.

Another responder mentioned that the subject matter made it difficult to pull the poster from circulation: "Due to the nature of it being for banned books, I think that I would have been disappointed that that had been the reaction" (Librarian blogger). However, the same interviewee also offered a more ambivalent opinion later in the interview:

Well, I mean I just, I don't know, just banning it outright I think would have been unfortunate due to the subject of what it was supposed to be about you know. But obviously if it offends someone, then I don't want anyone to be offended, so I had a hard time coming out and saying one way or another, this definitely has to happen. Overall I just don't want people to be offended, and I don't want anything that, from ALA, from, like, the biggest, you know, organization of librarians, to come out as being offensive to anyone because that is not what we're about, and I don't want this to be seen by the larger public to be something that is offensive coming from this big group of librarians, you know. (Librarian blogger)

As discussed, the OIF staff was primarily in agreement that pulling the poster would be a form of censorship.

So I worked on the blog post that was out initially, and we had sessions about whether or not, you know, the poster should be pulled or not, and, you know, my personal position was and always is and shall be that, you know, the last thing an office that deals with censorship should do is, you know, withdraw a poster unless there was, you know, we just, we counsel librarians daily on, you know, doing, you know, fighting the good fight and standing behind materials and things like that, and I just felt that we, if the first thing we did in the face or criticism was withdraw the poster, it would just undermine our credibility on the issue of censorship in the face of criticism-it's just that. (OIF staff 3)

It should be noted that this was the subject of discussion among the staff during the meetings regarding the response to the controversy. As one staff interviewee stated: "People were ... like, we should just pull this poster. And I stood up, I'm like, no, we can't pull this poster; we would lose credibility if we did; we can't, I mean, so we, the compromise was we'll let this poster fade into the background and have this other poster as, you know, as the alternate but still continue to sell both. That was the compromise" (OIF staff 1).

\section{Social Responsibility and Social Justice}

The themes of social responsibility and social justice within librarianship were two of the most prominent in the interviews. Both OIF staff members and librarians wrestled with how the 
poster did or did not support these core values. Of particular importance, because none of the responders identified as Muslim, was the issue of what it meant to be an ally to cultural and racial minorities in the United States. As noted in the literature review, support for issues of social responsibility have long been controversial within the ALA in particular and in librarianship as a whole. Social justice, especially the values of inclusion and diversity, has more recently become a concern in both the organization and the profession.

One of the interviewees brought up one of these historical controversies in response to a question regarding how to define intellectual freedom. Specifically, the responder discussed the film The Speaker and its relationship to the controversy over the 2015 poster:

No, my sentiments were very much with the E. J. Josey camp in the controversy over The Speaker, and you know, I was concerned that the bringing up again of the issue of The Speaker at the last ALA conference in a kind of historical context was going to not do, was not going to do justice to the issues that were really tearing the association apart at that time over the film. And, you know, I have the distinct feeling it was a kind of whitewashing, so to speak, of the whole affair-an attempt to make it, you know, just a kind of historical relic, which was not really, you know, which was something that we had somehow overcome or, you know, which no longer was, you know, really present and relevant. But I think that the interesting thing about the ALA poster, the OIF poster controversy was that it showed that, you know, some of those issues really still are relevant. Well, that's the context in which I thought, you know, maybe, that's what my acculturation of the library world —-that's how I immediately thought as part and parcel. (Special librarian 1)

Here the librarian states that the controversy over the BBW poster demonstrates that the ALA has continued to whitewash certain issues even 40 years after The Speaker was first an issue for the organization.

Some of the interviewees also perceived that social responsibility and social justice are not a priority for the ALA and the OIF. One responder simply states that the OIF does not care about these issues: “They're extremely conservative in things like that. . . Being socially responsible is something that they're not particularly interested in. Let me just put it that way" (School librarian 2). This sentiment was echoed by a public librarian who noted that the ALA had acted disrespectfully toward its own membership:

And just, you know, if it's censorship because we, just sort of, like, we don't want to be PC [politically correct]; I saw people saying that on Facebook. And it's like, it's not PC; it's respectful. You know, and I just felt like that was, I don't know, who they talked to because that wasn't clear. I know they didn't speak to me and I know they didn't speak to some of the other people that I know who both are, belong to and work in that 
community, but I felt like the whole thing was just sort of handed down in a disrespectful way. (Public librarian 7)

These interviewees clearly argue that the ALA and the OIF are not dedicated to social responsibility and, by extension, this lack of commitment led to the association publishing a poster that offended at least some of its members.

According to some of the interviewees, the ALA's lack of alignment with social justice meant that the association was a hindrance to the profession. A few interviewees stated that they had a responsibility to their patrons and community members and that the poster made it difficult to fulfill these responsibilities. One responder who works at a public library with a Muslim constituency stated that the poster could not be used there:

I mean the original design was extremely problematic for me. I do have women here you know who use my library who wear the full burqa as well as women who wear the hijab so this image, I had a lot of, I had a lot, a lot, a lot of problems with this image, and I, there's no way that I would post this image in my community, just absolutely no way because I do have those members of my, you know, the members of my community who are of the faith, but then mostly my neighborhood is a largely working-class African American neighborhood, and this kind of stuff is just, I mean, this kind of stuff is - to me, that image was doing the opposite of what we were trying to do. It seemed like it was calling out and objectifying and making the Other of a part of our population, and it just wouldn't be effective for my community. (Public librarian 5)

This argument was persuasive for Academic Librarian 2, who discussed seeing problems with the poster once they were pointed out by a fellow librarian who works with the Muslim community.

These concerns with representation and community lead directly to the issue of how to best be an ally to those who lack power in society. For example, interviewees were concerned about who should be empowered to speak on behalf of the Muslim community. One noted being unsure of having something to contribute to the discussion because this person was not personally affected by the poster: "I am not a part of the demographic that is depicted and so I didn't really chime in so much in some of these more public forums; I mean, public; I guess I put my opinion out on the internet, but I wasn't really participating; I was more kind of lurking and watching these discussions in like the Facebook group just because I, you know, not being a member of the demographic, I wasn't, I didn't really feel comfortable kind of coming out and being offended for them" (Library consultant and blogger). This interviewee was uncomfortable with the idea of standing in for an underrepresented group.

For another interviewee, speaking up for others was not as a difficult as it was for the interviewee above, but it required having "cultural humility": "Incorporating the idea of cultural 
humility into everything would be part of it, so that you were aware that there [is] different cultural potential for not considering different cultural ways people are. And so what may seem okay to the Office for Intellectual Freedom may not be okay to someone who's going to be impacted by that" (LIS postdoc). These concerns were echoed by OIF staff members. For example, one person summarized her views: "I think people meant well but . . . I think that one of the things that might've been helpful is when the individuals who became concerned after seeing the thumbnail of the image started to become concerned about cultural insensitivity, it would've been nice if they had checked with a broader group of culturally diverse people to check with them for how they felt about it" (OIF staff 2).

Apparently unbeknownst to most of the responders, the OIF is a diverse group of people who actively seek out diverse viewpoints (e.g., from the design firm). As the previous OIF staff person indicated, many responders did not, in fact, seek out diverse perspectives on this poster. This led to frustration and anger within the OIF, as noted by another staff person: "What's interesting about this to me is the outrage on my staff-the people of color on [the] staff who were just so angry at the white liberal response to it" (OIF staff 5).

Librarianship is a very white profession (Rubin 2010), and some interviewees argued that part of the problem was simply that the ALA itself is unaware of its white privilege (again, this argument may seem ironic in light of the diversity of the OIF staff). For the following interviewee, this means that not enough people (particularly on the Intellectual Freedom Committee) would have the awareness to pull the poster before it went to production:

So I reached out to some friends and colleagues on council who are in some of the ethnic caucuses to say that, you know, this is a great opportunity for, you know, what I think of as a blind-to-white-privilege, ALA kind of mindset; you know, it's a teachable moment. The Intellectual Freedom Committee historically has been extraordinarily white. It's not so much in recent years, and that's a good thing, but the IF [Intellectual Freedom] community needs to hear way more from people of color. And, you know, this is an example of where, you know, enlightenment values of universal kind of principles is kind of propping up white privilege. (Academic librarian 2)

More plainly, another interviewee argued that the ALA (i.e., meaning the staff, not the members) are not true allies, as they do not take active social justice stances in the face of racism: "I think of the people at ALA as very well-meaning people, but it's different not being a racist and being antiracist, for example. I think the people at ALA are by and large not racist; you know, yay for you, but I don't think they actively combat racism and issues with multiculturalism and issues of diversity in ways that I feel would be progressive" (Librarian). Here being antiracist, an active position, is contrasted with not being racist, a passive position. For 
this interviewee, because the ALA fails to take an active stance against racism, it is not a progressive organization.

Although the interviewees quoted above all had problems with the poster, others argued that the association was actually fulfilling its social responsibility obligations with the poster. For example, one interviewee stated that the association would never be deliberately offensive: "It's ludicrous to think that the Office for Intellectual Freedom and ALA would promote something that would be prejudiced—one of the most inclusive associations I think that I've ever seen. We welcome diversity in our association" (School librarian 1).

It is clear from the excerpts above that the ALA continues to be a site of tension over the social responsibilities of the profession. What values the organization should support, and how it should do so, remain ongoing problems for its administration and some of its members.

\section{Discussion}

This research project has highlighted several important issues for the ALA and its constituents. First, as described, the relationship between the OIF and some members of the ALA appears to be damaged. It is hard to quantify this relationship; those disaffected may be merely a pocket of dissatisfaction. A petition requesting removal of the controversial poster received approximately 300 signatures at the height of this controversy; however, that number pales in light of the overall membership of the ALA, of approximately 60,000 people. Nonetheless, it seems clear that some librarians-including those who are passionate about intellectual freedom issues-are unhappy with the OIF. This has the potential to exacerbate tensions within the ALA and to potentially affect the financial health of the OIF or the ALA itself. At the same time, those voices of discontent are important for the OIF to hear, particularly in light of the points that follow.

Second, there is ongoing tension about how the profession defines censorship. In general, the ALA and the OIF use broad definitions of censorship, including many actions and positions. In part, this enables the OIF to support librarians who are facing challenges or requests to relocate or restrict certain materials. Many within the profession similarly view censorship broadly. However, this project found tension between the standard, broad definitions of censorship used within the profession and the actions that some members wished the OIF to take (i.e., removing the poster). For these responders, a narrower definition of censorship seemed more appropriate; as a result, some of them found themselves making arguments similar to those used by book challengers, which are likely at odds with the profession at large. It is unclear whether these responders would defend such a narrow interpretation in other contexts-if, for example, library resources were challenged in their own libraries. Even without ascertaining that, this tension remains. Certainly some (perhaps many) librarians view censorship more narrowly than the ALA does. This disagreement can further exacerbate the tensions 
between the members and the administration of the organization. If a core activity of the OIF is to defend against censorship but most individuals disagree about the meaning of censorship, then those individuals may disagree with the OIF's rhetoric and actions.

Third, this project found significant tension and discomfort around the issues of social responsibility, social justice, and intellectual freedom. This tension has long been a part of the ALA and will likely continue into the foreseeable future. It is a tension born of conflicting perspectives and priorities. Those who prioritize intellectual freedom—namely, the OIF — see social justice concerns as claims that could reduce access to certain opinions and perspectives. Alternatively, those who prioritize social justice argue that the status quo of intellectual freedom means that some voices are marginalized and silenced-corrective action is needed to ensure that disenfranchised perspectives can be disseminated. Calls for librarianship to respect and elevate the marginalized voices within our society are increasing. A strict stance on intellectual freedom would resist these calls. Hence, the tension revealed by this controversy is about more than a BBW poster: it is about the future direction of the profession itself.

In addition, this research revealed tension about how social justice advocates interpret and apply social justice principles. For example, most of the responders were white; none were Muslim. Some-but not many_felt discomfort in what they perceived as speaking on behalf of minority voices. Certainly, the diverse staff of the OIF recognized the awkward and perhaps inappropriate act of white liberals speaking for (and over) those less privileged. If the profession is to take more of a social justice stance, then it must do so thoughtfully. The ways in which marginalized voices can be sought out, respected, and listened to must be carefully considered and applied.

\section{Conclusion}

Although this controversy might seem to be of little consequence, it is, in fact, the latest skirmish in a long-standing argument in American librarianship over the place of social responsibilities within the ALA. As several LIS historians (Geller 1984; Samek 2001; Good 2008; Jensen 2008) have noted, the clash between neutrality and social justice has marked the values of librarianship since its establishment in the late nineteenth century. The controversy over the 2015 BBW poster comes at a time when LIS students, educators, and professionals are calling for a field that takes a critical stance toward power and the status quo. As this research has demonstrated, the discourse surrounding the poster revealed these long-standing tensions within librarianship.

\section{Appendix}

\section{Initial List of Interview Questions}

Because these were semistructured interviews, the discussion sometimes took off in unexpected directions. Some questions may not have been asked. Other questions, particularly questions asking respondents to elaborate, may have been added. 


\section{Cluster 1: Librarians and Other Information Professionals}

1. Do you and/or your institution usually "celebrate" Banned Books Week (BBW)?

2. What sort of activities do you do at your institution for BBW?

3. Do you usually buy materials from ALA for BBW?

4. When you saw the poster for this year, what were your first impressions? What led you to think this?

5. Were you surprised by the controversy around the poster? Why or why not?

6. What are your thoughts on the controversy?

7. Do you think the poster resembles a niqab? If so, in what way? What makes you think of the niqab?

8. Where do you stand on the controversy?

9. Do you think the Office for Intellectual Freedom (OIF) should redo the poster? Why or why not?

10. Are you satisfied or comfortable with the revised poster released by OIF? Why or why not?

11. Do you identify as male or female? Do you identify as Muslim?

\section{Cluster 2: Staff Members at the ALA OIF}

1. What is the process for the BBW materials design? When do you start the process?

2. When did you first see the poster for this year? What were your impressions?

3. When did you hear about the wider controversy?

4. Were you surprised by the controversy around the poster? Why or why not?

5. What was the office's response? Any follow-up?

6. Are you satisfied or comfortable with the revised poster? Why or why not?

7. Will there be any changes to the process for designing materials next year?

8. Do you identify as male or female? Do you identify as Muslim?

\section{References}

ALA (American Library Association). 2014. "The Speaker.” http://www.ala.org/tools/atoz/speaker.

ALA (American Library Association). 2016a. “ALA Annual Membership Statistics.” http://www.ala.org /membership/membershipstats_files/annual_memb_stats.

ALA (American Library Association). 2016b. "Library Bill of Rights." http://www.ala.org/advocacy/intfreedom /librarybill.

Berry, John N. 1977. “The Debate Nobody Won,” Library Journal 102 (14): 1574-80.

Geller, Evelyn. 1984. Forbidden Books in American Public Libraries, 1876-1939: A Study in Cultural Change. Westport, CT: Greenwood.

Good, Joseph. 2008. “The Hottest Place in Hell: The Crisis of Neutrality in Contemporary Librarianship.” In Questioning Library Neutrality: Essays from Progressive Librarian, edited by Alison Lewis. Duluth, MN: Library Juice.

Jaeger, Paul T., Nicole A. Cooke, Cecilia Feltis, Michelle Hamiel, Fiona Jardine, and Katie Shilton. 2015. "The Virtuous Circle Revisited: Injecting Diversity, Inclusion, Rights, Justice, and Equity into LIS from Education to Advocacy." Libraru Ouarterly 85 (2): 150-71. 
Jensen, Robert. 2008. "Myth of the Neutral Professional.” In Questioning Library Neutrality, edited by Alison Lewis. Duluth, MN: Library Juice.

Kagan, Al. 2014. "Editorial." Progressive Librarian 42 (Summer): 4-9.

Knox, Emily J. M. 2014. "The Books Will Still Be in the Library: Narrow Definitions of Censorship in the Discourse of Challengers." Libraru Trends 62 (4): 740-49.

Lilleker, Darren G. 2003. "Interviewing the Political Elite: Navigating a Potential Minefield." Politics 23 (3): 207-14.

Morehart, Phil, and George M. Eberhart. 2014. “Resurrecting The Speaker.” American Libraries Magazine, July 1. http://americanlibrariesmagazine.org/blogs/the-scoop/resurrecting-the-speaker/.

Oltmann, Shannon M. 2016. "Qualitative Interviews: A Methodological Discussion of the Interviewer and Respondent Contexts.” Forum Qualitative Sozialforschung/Forum: Qualitative Social Research 23 (2). http:// www.qualitative-research.net/index.php/fqs/article/view/2551/3998.

Patton, Michael Quinn. 1987. How to Use Qualitative Methods in Evaluation. Newbury Park, CA: Sage.

Raber, Douglas. 2007. "ACONDA and ANACONDA: Social Change, Social Responsibility, and Librarianship." Libraru Trends 55 (3): 675-97.

Robbins, Louise S. 1993. "Segregating Propaganda in American Libraries: Ralph Ulveling Confronts the Intellectual Freedom Committee." Library Ouarterly 63 (2): 143-65.

Rubin, Richard. 2010. Foundations of Library and Information Science. Chicago: Neal-Schuman.

Samek, Toni. 2001. Intellectual Freedom and Social Responsibility in American Librarianship: 1967-1974. Jefferson, NC: McFarland.

Emily J. M. Knox: assistant professor, School of Information Sciences, University of Illinois at Urbana-Champaign. Knox's research interests include information access, intellectual freedom and censorship, information ethics, information policy, and the intersection of print culture and reading practices. Knox recently edited Trigger Warnings: History, Theory, Context, published by Rowman \& Littlefield. Knox's book Book Banning in 21st Century America was also published by Rowman \& Littlefield and is the first monograph in the Beta Phi Mu Scholars series. Knox serves on the boards of the Freedom to Read Foundation and the National Coalition against Censorship. E-mail: knox@illinois .edu.

Shannon M. Oltmann: assistant professor, School of Information Science, College of Communication and Information, University of Kentucky. Oltmann's research interests include censorship, intellectual freedom, information policy, public libraries, and qualitative research methods. She has presented her research at academic conferences such as the Information Ethics Roundtable, the annual conference of the Association for Information Science and Technology, the iConference, and the International Congress on Qualitative Inquiry. Her work has been published in the Journal of the American Society for Information Science and Technology, Library Quarterly, Public Libraries Quarterly, Collection Management, Libri, and Science and Engineering Ethics. E-mail: shannon.oltmann @uky.edu. 